\title{
MUSHROOM FARMER'S DILEMMA: MARKET DEPENDENCE AND ENVIRONMENTAL POLLUTION THREAT
}

\author{
Angga Prasetyo Adi \\ Master Program Rural Sociology \\ Bogor Agricultural University \\ Email: anggasatrodarsono@gmail.com
}

\begin{abstract}
Abtracts
In critical reviews on here I write under the title dilemma mushroom growers to the pressures of globalization and capitalist sheath through ecotourism which resulted in the pollution of the environment. In this article use using work unpaid are pointed Alvin A Camba (2018) which describes the regime of food in the colonial period in the Philippines in the article here I try abtract dilemma mushroom growers area of jungle fighting that produce mushrooms worth matrial is quite high but it is also the existence of a environmental threats due to fighting forest used as a tourism icon for Bangka middle that invites tourists to enter and threaten the environment with the waste that was taken. Because, ecotourism managers who are fighting the forest does not have the tools for waste management, but it is also packing systems made by managers who are still using plastic that will keep growing volume of plastic waste. Mushroom packing pattern which will be marketed through the jungle fighting travel does not have the technology to avoid the use of plastics.
\end{abstract}

Keyword: Food Regime, Environmental Sociology, Ecology Economy

\section{Introduction}

Forests provide tremendous revenue for the community with a variety of natural resources that are provided. Here is explained that the resources generated by the forest is a form of unpaid labor are seen from the " appriori " and was previously a capital accumulation process involving the appropriation of unpaid labor with nature (Camba, 2018). If you look at the relationship of capital accumulation through " appriori " is a precondition for the extraction of more value for the capitalist. Fighting forest is a protected forest that provides value to the form of unpaid work for fighting forest or resource in the form of fungus that, have sales value high enough but it is also their wild honey. Fighting forest itself has an area of 12.4 ha (KLH Bateng. 2016). The accumulation of unpaid capital value which is part of the process of capitalist production that did not get put out of production, then there is the elite elite enjoying their unpaid benefit values generated by forests such as mushrooms as a contrarian market needs. Therefore, it needs not farmers who benefit, but there is in part Namang village elite who benefit agriculture mushroom result of 
unpaid value fighting forest.

The accumulation of capital through the form of unpaid labor of fighting forest like a double-edged aside other hand also destroys beneficial with environmental pollution generated by tourism. With the tourism industry who entered as a series of global capitalist to exploit forest resources without knowing the cultural values of being owned by people on the forest fighting. It also impacts the accumulation of capital by the existing waste also affects the relationship in addition to fighting forest also with the exploitation of the plant such as mushrooms and honey provide breeding and reproduction fees are charged by farmers as working requirements which therefore causes the non paid work.

The purpose of this research is as an initial identification of the presence of capital collected into non-capital village communities and changing the existing system in the community, such as what happened in the opposing forests of Namang village. The cultural system in the mushroom production patterns in the farmers' villages is opposed, which changes and shifts to a village that uses capital that collects capital both in the mushroom and ecotourism fields. Because with the development carried out by ecotourism-based government, creating new problems with waste problems. In this research, showing the farmers about protection against mushrooms, in Namang village, the area of contiguous forest becomes important because nature is an addition as a study material for decision makers to look at the cultural aspects and the relationship between mushroom farmers in the production process.

\section{Research Methodology}

This research uses qualitative research specifically for literature study using books and other literature as objects, the type of research used is qualitative research that produces and can list descriptions of the data available in the text. (Mantra, 2008). With qualitative research, descriptive analysis needs to be done. Descriptive analytical methods provide clear, objective and critical descriptions and descriptions of the dilemma of mushroom farmers in the rainforest on the entry of their associated capital in the market besides the problem of waste generated by tourists who come to the rainforest. Data is needed at the initial stage which is collected by collecting the required data then classification and description are carried out.

In this study the dilemma of mushroom growers in the forest of contrarian sources obtained primary and secondary sources. The primary source is a reference that is used as a reference in the study of the dilemma of mushroom farmers who are engaged in using mealtime at the end of the Philippine occupation: Pathway sofap propriation and unhelped work. This is used as an idea for analyzing how to make a payment made 
from high-value nature. Second, using the food and agrarian regimes, questions which become an analysis of the form of farmers of capital entering into the forest of contrarians. Second, using secondary data is a supporting and complementary reference for primary sources in research such as data from the central statistics agency, data from the Ministry of Environment and Forestry and the local knowledge community as an effort to fight forest conversion in Bangka.

Data collection methods in library research methods used to collect and research in the form of library data that has been selected, sought, presented and analyzed. The data presented in the form of data that has been simplified using the word continue is complete and systematic (Muhajir, 1998). Data that has been collected is then analyzed to obtain information, but previously the data was filtered on the basis of its reliability (Mantra, 2008). Data analysis in this research uses data analysis techniques in the form of content analysis is a scientific analysis of the contents of data messages (Muhajir, 1998)

\section{Economic and Political Transformation Farmers}

If you look at the relationships that occur in the production process does not work pay then occurred the existence of a dynamic economic and political relations Namang village farmers fighting forest area. Capitalist who fall into relationships that occur in the production process with a mushroom farmer who originally as a form of relationship based on values now change the relationship with labor relations that are based systems that oppress and exploitative capitalist with unpaid work generated by Pelawan forest resources. Additionally, Central Pacific Islands government also agrees with the exploitation of resources of forest resources through fighting forest regulations stating that the forest area used as a garden Pelawan biodiversity middle Bangka district that serves as ecotourism and green open spaces.

The dynamics of the economic structure based farmer turned economy household economy ladder industry. the value of fungus-fighting makes some farmers want to cultivate fungus-fighting on a large scale but fungus-fighting the classified hard to get cultivated because it relies on the natural growth around the tree so that no values in the community who believed the appearance of fungus-fighting after drought followed by rain accompanied by lightning. In the production of these mushrooms rely on animals, especially mammals that dig transform and spread of spores. But, the dilemma be essentially mushroom growers are not able to enjoy an optimal result of the fighting fungus because the fungus is dominated by artisan craftsmen who they sell these herbs."the global of value comes from the differential forms of labor as world historical expressions of capitalism "(Camba, 2018). Here are the dynamic soft the economy of mushroom grow erswith craftsmen fungus 
mushroom grow ersseemed to be a substance in the processof farming that was so rely missing, and the refore the farmers have a view that they choose to sell their land to foreigners because it was felt the rewas No. longeranad vantage in the process of farming mushrooms though prices fungus-fighting is very expensive.

In dynamics the economy there is a village elite elite who benefited in the production process because of perceived fungus fighting have the value of a fairly high costof production is quite cheap. The village elite elite profit make the conflict between craftsmen mushrooms with mushroom growers contrarian. Substantially benefit resulting from an increase in fungus fighting resulting from the forest is not a farmer but a few crafts men who have a relationship with the government that makes the forest fighting as ecotourism as a pretexttoin creasein crease revenues and to meet global food for fungus-fighting classified as function which has a high enough value in the global market.

\section{Production threat Plastic Waste}

In the process production of capital like two sides of a coin how the production of capital also boost the economy but on the other hand there are massive ecological destruction. The destruction of the ecological consequences both economically and culturally because of their knowledge of the fight between capital and society. As knowledge of the local community can be used as one of the efforts in supporting the integration of conservation and development of natural resources and the potential of forest ecosystems contrarian. Tourism-based economic activity makes the existence of a separate threat to the ecology of the sustainability forest Pelawan that it also affects the economy of the village farmers Namang. The existence of a boost existing indigenous communities became an important capital in support of forest ecotourism program Pelawan. It is relevant to unpaid production potential resulting from forest Pelawan developed became the object of the appeal of ecotourism. A special attraction for Pelawan forest area to be used as ecotourism potential to attract tourists and to support the local community economy. With the appeal of entering the forest area that serve Pelawan attractions on the other hand provide benefits to the community with their economy make people's lives much better. But that becomes the problem that the presence of ecotourism into the area carrying a plastic trash make their environmental problems Pelawan forest region. A special attraction for Pelawan forest area to be used as ecotourism potential to attract tourists and to support the local community economy. With the appeal of entering the forest area that serve Pelawan attractions on the other hand provide benefits to the community with their economy make people's lives much better. But that becomes the problem that the presence of ecotourism into the area carrying a plastic trash make 
their environmental problems Pelawan forest region. A special attraction for Pelawan forest area to be used as ecotourism potential to attract tourists and to support the local community economy. With the appeal of entering the forest area that serve Pelawan attractions on the other hand provide benefits to the community with their economy make people's lives much better. But that becomes the problem that the presence of ecotourism into the area carrying a plastic trash make their environmental problems Pelawan forest region. With the appeal of entering the forest area that serve Pelawan attractions on the other hand provide benefits to the community with their economy make people's lives much better. But that becomes the problem that the presence of ecotourism into the area carrying a plastic trash make their environmental problems Pelawan forest region. With the appeal of entering the forest area that serve Pelawan attractions on the other hand provide benefits to the community with their economy make people's lives much better. But that becomes the problem that the presence of ecotourism into the area carrying a plastic trash make their environmental problems Pelawan forest region.

In addition to introducing the natural potential in fighting forest through tourism but also creates new problems for forest fighting the absence of a plastic waste processing. Therefore, the plastic waste in fighting forest area is the source of livelihood of farmers is threatened due to the trash affect the surrounding environment Pelawan forest. So, the concept of Jason w Moore that capitalism is also able to make their economic boom but on the other hand the destruction of a large lakeside ready to threaten to nature provide unpaid production. But, on the other hand with the tourism in fighting forest with mushrooms potential makes the existence of a packaging that arguably does not favor the environment. Here are explained by the indirect threat is plastic packing process carried out by craftsmen mushrooms which will be marketed not afford environmentally friendly packing due to limited material resources as well as technology. On the other hand the forest area Pelawan make their tools or environmental management because the government as the holder power not able to provide or give out ecotourism management so well that the threat of a plastic garbage about continues to be a scourge to society Pelawan forest farmers who rely on life in the production process is not paid.

Therefore, it is in integrating conservation of forests sustainably fighting the indigenous communities as a basic ethical concern for the environment persists. Therefore, it is the indigenous communities have an important role in making them. The few ways that embody the indigenous communities with their revitalization and actualization. In addition, the legal umbrella as a base strength to occur and have a positive impact on the environment the lives of people. 
Their plastic waste dilemma felt by mushroom growers because the other side of the economic improvement of ecotourism in attendance but on the other hand they should be ready to increase the volume of waste that threatens the ecological effect on mushroom production.

\section{Conclusion}

Pelawan forest a forest providing unpaid production because the production process results such as the fungus is not created through the production process with cost but through the workings of nature. in the production process affecting economic factors such Namang to village community for the transition of the system that work based on subsistence farmers but with their ecotourism established by the Central Bangka regent decree made on the basis of the subsistence needs turning into the industry in order to fulfill global compliance. with increased production happens also affect relations with the farmers where the fungus is not just raw or capital circulating capital but have complex relationships or even fungus almost like his own family. Ecoturism is not without challenges the environment is largely from waste generated by forest visitors because the central Bangka government do not have the technology to process waste that requires plastic waste that is difficult to break down for the survival of farmers and environment as a source of livelihood for forest farmers.

\section{Reference List}

Eric holt Gimenez and annie Shattuck 2011. food crises, food regimes and food movement: rumblings of reform or tides of transformation ?. London: the journal of peasant studies.

Jason W. Moore. 2015.Capitalism in the web of life: ecology and the accumulation of capital. London: Verso Press

Kementerian Lingkungan Hidup dan Kehutanan, Pusat Pengendalian Pembangunan Ekoregion Jawa, 2016. Bangka Tengah http://www.menlhk. go.id

Ida Bagus Mantra.2009. Demografi Umum. Yogyakarta: Pustaka Pelajar Offset

McMichael, Philip, 2004, Development and Social Change. A Global Perspective. Third Edition, Pine Forge Press.

McMichael, Philip, 2013. Food regime and agrarian questions. Canada: Fernwood Publishing

Van der Ploeg, JD, 2008, The New Peasantries. Struggles for Autonomy and sustainability in an Era of Empire and Globalization. Earthscan Publishing for a sustaibable futures.

Camba, Alvin A 2018. The foodregime in late colonial Phillipines: Pathway sofap propriationandunp aid work. JournalofAgrarianChange

Henri luchmanjudgesandteakbataro 2018. Local knowledge society as fighting forest conservation efforts in Bangka district center, the Pacific Islands. Semarang: Diponegoro University 
Noeng, Muhadjir. 1998. Metodologi Penelitian Kualitatif. Edisi ke III cetakan ke 8. Yogyakarta: Penerbit Rake Sarasin.
J. Creswell 2015, Penelitian Kualitatif dan Desain Riset Memilih Di Antara Lima Pendekatan. Yogyakarta: Pustaka Pelajar. 